\title{
Entre o procedimento formal e o conteúdo selvagem: imanência e democracia em Jürgen Habermas e Antonio Negri
}

Pedro Luiz Lima'

\author{
"É evidente que todas as formas políticas consideram \\ a democracia como verdade e que, portanto, apenas são \\ verdadeiras quando são democráticas".
}

(Karl Marx)

\section{Resumo}

A partir de uma análise crítico-comparativa das teorias da democracia de Jürgen Habermas e Antonio Negri, o presente artigo busca esclarecer os fundamentos conceituais de ambas as obras, tomando como eixo a discussão sobre o modo pelo qual suas concepções de democracia se inscrevem, cada uma, em seu respectivo plano de imanência. Com a premissa de que a leitura cruzada desses dois autores favorece uma mais aguda compreensão dos componentes estruturantes, implicações normativas e limites de suas teorias, objetiva-se situá-las como alternativas distintas (deliberação/substância), e potencialmente complementares (entendido o consenso como forma e conteúdo), para se pensar a questão democrática contemporânea.

Palavras-chave: Teorias da democracia. Imanência. Soberania. Jürgen Habermas. Antonio Negri.

\section{Introdução}

A questáo da democracia talvez seja aquela que, a despeito das contingências de cada contexto discursivo, mais propriamente pode ser descrita como uma das incógnitas perenes da história da filosofia política. Desde a revolta

Doutor em Ciência Política pelo IESP-UERJ e Professor Adjunto do Departamento de Ciências Sociais da Universidade Estadual de Londrina (UEL). E-mail: pedrollima@gmail.com.

2 Agradeço aos pareceristas de Política E Sociedade cujos apontamentos contribuíram substantivamente para a versão final do presente artigo. 
platônica contra os efeitos perversos de um regime capaz de condenar democraticamente o filho mais virtuoso da polis até o atestado de óbito da história pela suposta eternização dos moldes ocidentais-capitalistas de democracia liberal - em boa parte dos momentos desta trajetória acidentada, a filosofia política, entendida não de maneira unívoca, mas antes como conflito de filosofias, parece se referir, negativa ou positivamente, ao problema democrático.

E se nas sociedades ocidentais contemporâneas, em seu discurso político oficial, a democracia aparece, no mais das vezes, como conceito taken for granted, imobilizado por mecanismos eleitorais, espetacularizado nas imagens midiáticas e submetido à mercantilização pela lógica expansiva do mercado; se esta é, de fato, a tendência geral, então, tornam-se necessárias investidas conceituais que não apenas desvelem as especificidades e limites desta forma política, mas que também concorram para a definiçáo, mesmo que tateante, de possíveis rotas de aperfeiçoamento.

Nesse sentido, para além das necessárias investigaçóes acerca dos mais eficazes mecanismos de accountability e da busca pelo aprimoramento da prática eleitoral que constituem parte do corpo da ciência política, faz-se mister retomar a empreitada, de caráter mais abstrato, da investigação teórico-conceitual dos pontos de ancoragem normativa e dos múltiplos sentidos das concepçóes contemporâneas de democracia. É neste quadro que as teorias da democracia de dois dos filósofos políticos mais notáveis desta virada de século, Jürgen Habermas e Antonio Negri, aparecem como profícuos pontos de partida. Ainda que Habermas construa sua noçáo de democracia pelo mergulho reconstrucionista nos próprios fundamentos do Estado constitucional moderno, enquanto Negri o faz ao inscrever sócio-historicamente a ontologia de pensadores como Espinosa - mesmo nessa disparidade, é possível, a nosso juízo, reconhecer um propósito comum, de pensar a democracia para além da sua redução a certas formas políticas que a enredariam e impossibilitariam sua efetividade.

Neste artigo, um dos postulados centrais a ser desenvolvido, que fundamenta a possibilidade de uma análise crítica das obras de Negri e Habermas, diz respeito a um imanentismo indissociável de suas concepçôes de democracia. A despeito das inúmeras especificidades que caracterizam e diferenciam seus projetos teóricos, é possível pensar ambas as filosofias como herdeiras da crítica do jovem Marx aos Princípios de Filosofia do Direito, de Hegel - crítica 
que incidia decisivamente sobre a ascendência do Estado sobre a sociedade civil. Se a democracia é "forma e conteúdo" a um só tempo, ou antes, se ela é o "enigma revelado de todas as constituiçóes" (MARX, 2005, p. 49-50), é precisamente porque ela não se aloja por sobre a sociedade como mera forma de governo, mas antes deve ser procurada no nível do conteúdo, ou seja, no próprio seio da sociedade - em um plano de imanência.

Definido este solo comum de onde partimos para analisar e contrapor as perspectivas de Habermas e Negri, convém notar que não se pretenderá realizar, no que segue, um exercício de mera aproximaçáo dos dois pensamentos, de suas categorias e conclusôes. O objetivo aqui é, antes, explorar tanto alguns pontos de interseção quanto outros momentos de afastamento, a fim de melhor identificar algumas vicissitudes do pensamento democrático contemporâneo.

Em suma, trata-se de demarcar o diverso terreno conceitual a partir do qual as teorias da democracia de Negri e Habermas podem emergir, e assim definir algumas reviravoltas analíticas que as aproximam, onde pareceria corriqueiro afastá-las, e as distinguem, por sentidos pouco explorados na literatura secundária. Com a premissa, que se pretende confirmar ao longo da exposição, de que a leitura crítica em conjunto de ambas as teorias da democracia favorece uma mais aguda compreensão de seus componentes estruturantes, de suas implicaçóes normativas e de seus limites - com tal premissa, espera-se contribuir para um mapeamento mais rigoroso do panorama contemporâneo da teoria democrática.

Na primeira parte deste artigo, tratar-se-á eminentemente de desenvolver a tese segundo a qual as teorias dos dois autores apontariam para (e se construiriam em) um plano de imanência, fundamentando-o, contudo, de modo diverso, a partir das categorias de razão, para Habermas, e desejo, para Negri - categorias, estas, que se desenvolvem a partir de tradiçóes filosóficas distintas: via Kant e Hegel, no primeiro caso, e via Espinosa, no segundo. Esta primeira definição dos fundamentos parece-nos, com efeito, um passo crucial na busca por uma interpretação mais densa da relação entre suas concepçóes de democracia e por uma análise crítica da "compreensão do presente" que se efetiva através delas. $\mathrm{Na}$ segunda parte do texto, aquelas concepçóes serão diretamente investigadas, tendo como eixo central a relação que entretêm com 
o direito e com o princípio da soberania (Michel Foucault será então um interlocutor prioritário). Neste passo, ambas as teorias aprofundariam uma divergência já notada no estudo inicial de seus fundamentos - através da recusa, comum a ambos, de estabelecer um vínculo entre democracia e uma soberania transcendente - e assim se colocariam como alternativas distintas (deliberação/substância), e potencialmente complementares (o consenso como forma e conteúdo), para se pensar, hoje, a questão democrática.

\section{Imanência, Razão e Desejo: questões de forma e conteúdo em Habermas e Negri}

"A razão comunicativa opera na história como uma força vingadora". (Jürgen Habermas)

"Ir além da modernidade significa ir além dos limites e transcendências do eurocentrismo, e conduz à adoção definitiva do campo de imanência como o terreno exclusivo da teoria e prática da política".

(Antonio Negri)

Admitir Habermas como um pensador da imanência pode parecer, de partida, uma assunção arriscada. Em meio a teorias da pós-modernidade que postulam um ultrarrelativismo contextualista talvez mais afeito, em princípio, a um pensamento de imanência, Habermas tem o mérito de, a nosso juízo, manter-se em um horizonte imanentista e, ao mesmo tempo, superar a paralisia provocada pela explosão pós-moderna de alteridades absolutas - e o faz por intermédio do que poderíamos chamar de um universalismo rarefeito da razão.

Para melhor defini-lo, há que se verificar a maneira pela qual o filósofo alemão constrói seu pensamento pós-metafísico, alicerçando-o em um universalismo racionalista que precisa, para manter-se nos limites da modernidade, andar em uma corda bamba - entre a transcendência e a imanência. Nesse sentido, acompanhemos brevemente Habermas no caminho que o leva para além das aporias do discurso filosófico inaugurador da modernidade. Em 
seu projeto racionalista, o ponto de partida crucial se situa na compreensão do problema da modernidade tal qual posto por Kant e Hegel - problema que permanece precariamente resolvido no arcabouço conceitual dos dois pensadores.

$\mathrm{O}$ peculiar da modernidade, para Habermas, e um dos fatores que nos situa necessariamente no seu interior, é a desvinculação progressiva da integração social de sua anterior fundamentação religiosa, mitológica ou metafísica. Tornada órfá destas fontes transcendentais de legitimidade por um processo de esclarecimento (ou racionalização), a sociedade moderna passa a conviver com a crise de uma integração que agora não pode mais apelar a um lado de fora para a determinação de parâmetros morais e éticos. Primeiro momento, pois, em que a trajetória de Habermas já aponta para um plano de imanência que, aqui, parece se impor como obstáculo a uma solidariedade agora carente de fundamento. A esta altura, tanto o regresso a uma solidariedade mecânica ancorada em metafísicas ordenadoras quanto a aceitação passiva da implosão de qualquer fonte de normatividade são descartadas como tentativas precárias de fugir de um problema inescapável:

As forças religiosas de integração social debilitaram-se em virtude de um processo de esclarecimento que, na medida em que não foi produzido arbitrariamente, tampouco pode ser cancelado. É próprio ao esclarecimento a irreversibilidade de processos de aprendizado que se fundam no fato de que os discernimentos não podem ser esquecidos a bel-prazer, mas só reprimidos ou corrigidos por discernimentos melhores. Por isso o esclarecimento só pode compensar seus déficits mediante um esclarecimento radicalizado. (HABERMAS, 2002, p. 122).

Em busca da radicalização deste processo e para encontrar novo ponto de ancoragem para uma moralidade desfundamentada, a filosofia de Kant apresenta o sujeito racional como portador das categorias do conhecimento e, mais ainda, da capacidade cognitiva necessária à apreensão do objeto, à determinação de normas práticas que fundamentem os costumes e ao juízo estético.

A determinação objetiva de uma subjetividade emoldurada em abstrato leva Kant a ultrapassar o obstáculo da modernidade pela internalização das fontes normativas nos próprios sujeitos. Se a pré-modernidade dependia de uma imposição exógena de princípios fundantes dos costumes, na modernidade kantiana este legado é supostamente subvertido por um sujeito que se 
dá a si mesmo suas próprias normas, em conformidade com a razão prática. O esclarecimento, aqui, é entendido como uma libertação do homem, cujas possibilidades de saber teriam sido finalmente desacorrentadas do jugo tutelar de cosmovisóes opressivas (KANT, 1978, p. 25). "Sapere aude" é o lema da emancipação do sujeito, de sua reconciliação com um intrínseco potencial racional.

Se Habermas, por um lado, herda de Kant a necessidade deontológica de alcançar um patamar universalista, indispensável para sua fundamentação do estado democrático de direito, por outro, é preciso superar Kant na medida em que seu universalismo reside nas alturas transcendentais de uma subjetividade abstratamente concebida, e desvinculada do mundo concreto. Ao mesmo tempo em que a filosofia do sujeito kantiana reconhece a imposição moderna de uma fundamentação imanente dos costumes, ela esbarra na composição de um sujeito "suprahistórico" e, assim, eleva novamente seus fundamentos ao plano transcendental de que era imperativo fugir. Para além de Kant, ou antes, para aquém de seu transcendentalismo - e do ônus formalista da "subjetividade" que daí deriva -, Hegel procura encarnar, conferir concretude, à racionalidade.

Para fazer retornar o esclarecimento a um plano de imanência, Hegel inscreve a razão no interior da história. Não há mais um sujeito universal, portador incondicional da razão; na narrativa hegeliana, a razão perde o caráter de atributo subjetivo e passa a, com a história, ser compreendida como processo. É no interior do processo histórico, pois, que se realiza progressivamente a identidade entre razão e efetividade: "O que é racional é efetivo e o que é efetivo é racional” (HEGEL, 2003, p. xxxvi).

Assim é que à história passa a ser atribuído o porte de uma razão que precisava sair dos liames estreitos do sujeito. Com este movimento, Hegel ultrapassa a filosofia da consciência, apenas para cair, segundo Habermas, nas malhas de uma dialética teleológica que termina por desabonar os sujeitos e os contextos sociais de sua própria responsabilidade na constituiçáo autônoma de sua sociabilidade. Ou seja, a bem identificada necessidade de autocertificação da modernidade é resolvida com uma noção de razão que se desenvolve historicamente por sobre os sujeitos, reduzidos que estão (em uma caricatura talvez excessivamente rápida) a joguetes de um processo de realizaçáo do espírito absoluto. Nas palavras de Habermas, 
Como saber absoluto, essa razão assume, por fim, uma forma tão avassaladora que não apenas resolve o problema inicial de uma autocertificação da modernidade, mas o resolve demasiado bem: a questão sobre a autocompreensão genuína da modernidade submerge sob a gargalhada irônica da razão, já que a razão ocupa agora o lugar do destino e sabe que todo acontecimento de significado essencial já está decidido. Dessa maneira, a filosofia de Hegel satisfaz a necessidade da modernidade de autofundamentação apenas sob o preço de uma desvalorização da atualidade e de um embotamento da crítica. Por fim, a filosofia tira o peso de seu presente, destrói o interesse por ele e lhe nega a vocação para a renovação autocrítica. (HABERMAS, 2002, p. 6I).

Assim como o sujeito kantiano, a história hegeliana parece se descolar do plano de imanência e, por conseguinte, deixa irresoluta a questáo da modernidade. A Habermas, portanto, resta a persecução de um conteúdo normativo da modernidade que ele assemelha a um racionalismo intransponível - e que exige tanto o abandono da figura do sujeito em seus trajes kantianos, quanto a superação de uma história racional hegeliana.

Em defesa da razão, Habermas permanece próximo a Hegel em seu repúdio a concepções que enxergam no movimento do esclarecimento não a busca por uma fundamentação racional da ordem humana, mas o engodo de voliçóes subjetivas ou vontades de poder que manuseariam o nome da razão para seus próprios intentos ${ }^{3}$. O universalismo, afirma Habermas no contexto de seu "anti-pós-modernismo", não oferece muitas alternativas aos que pretendem criticar os escamoteamentos ideológicos encobertos no processo de esclarecimento, pois esta crítica requer, ela mesma, o apelo a um patamar universalista com relação ao qual se possam apontar possíveis lacunas (HABERMAS apud BORRADORI, 2004, p. 55).

Como, entáo, consegue Habermas driblar as insuficiências das versóes hegeliana e kantiana para o problema da autocertificação da modernidade e, a um só passo, fazer retornar a razão a um plano de imanência sem abandonar um universalismo?

3 "[...] Este remédio caseiro, que consiste em tornar dependente do sentimento o trabalho muitas vezes milenar do pensamento e do intelecto, talvez sirva para dispensar todo o esforço de cognição e inteligência racional dirigidos pelos conceitos do pensamento. Em Goethe (uma boa autoridade), Mefistófeles diz [...]: 'Se desdenhares da inteligência e da ciência, que são os dons mais altos da humanidade, entregas-te ao diabo e estás perdido"' (HEGEL, 2003, p. XXX). 
Ora, é precisamente através do conceito de razão comunicativa que o filósofo alemão pretende restituir o conteúdo normativo da modernidade. Por meio deste conceito, cuja descrição pormenorizada não cabe nos limites deste artigo, a razáo passa a operar no interior mesmo das práticas cotidianas de comunicação. Isso porque, para Habermas, haveria em todo ato de fala voltado ao entendimento a mobilizaçáo, ainda que inconsciente, de certos pressupostos pragmáticos do uso da linguagem que independem do contexto. $\mathrm{O}$ consenso definido no horizonte das práticas comunicativas requer o recurso a determinadas ideias de validade, verdade, coerência, dentre outras, que escapam da delimitação circunscrita e relativa a particularidades linguísticas. Nesse sentido, entrelaçando razão e comunicação, Habermas insiste na definição de uma racionalidade, mas desta feita, ela se mantém nos limites imanentes das práticas cotidianas de comunicação e, por conta disso, não sucumbe aos transcendentalismos do sujeito e da história. A razão comunicativa é, pois, razão situada e deve perder o seu poder prescritivo na medida em que pretende vincular o universal ao particular sem prejuízo da potência intersubjetiva de definição do plano ético. Subentende-se, aqui, um ato de fala que, buscando a validade de sua assertiva, deve vincular sua particularidade a uma justificação que ultrapassa os limites do contexto, uma vez que o válido requer a hipotética aceitação de uma comunidade ideal de interlocutores racionais. Esta concepção de razão, então, livra-nos do dilema de ter de escolher entre Kant ou Hegel. A razão comunicativa não é destituída de corpo, como se fosse a espontaneidade de uma subjetividade constitutiva do mundo, em si mesma alheia ao mundo, e também não constrange a história sob uma teleologia que se fecha num círculo" (HABERMAS, 1990, p. 178).

A razão em Habermas, pode, então, retornar ao plano de imanência da autodeterminação social de seus próprios parâmetros éticos, porque, por um lado, livra-se do purismo da razão pura e se inscreve, não monologicamente, mas sim dialogicamente no interior das práticas sociais corriqueiras; e, por outro, devido a esta própria inscrição, não pode prescrever o conteúdo destas mesmas práticas, cuja responsabilidade imanente não pode ser transferida para categorias absolutas. A minima moralia do imperativo categórico kantiano construído no isolamento de uma subjetividade pura é substituída, assim, por uma razão formal de caráter procedimental (EISENBERG, 2003, p. 129), que apenas se articula em meio às próprias práticas intersubjetivas. A forma, 
portanto, não pode predeterminar o conteúdo e, por conseguinte, a validade universalista necessária ao consenso racionalmente constituído não impóe de antemão o caráter de tal consenso.

Por seu turno, Antonio Negri - nosso outro protagonista -, erige também um plano de imanência, no qual irá situar sua noção de democracia; mas o faz de modo bastante distinto, e a partir de fontes teóricas distintas. Também impulsionado pela problemática marxiana com relação à necessidade de superação da distinção entre o político e o social, Negri busca principalmente em Espinosa uma fundamentação ontológica do político que se contraponha ao transcendentalismo jusnaturalista.

Aqui, assim como foi preciso recuar até Kant e Hegel para propriamente identificarmos o contexto conceitual em que Habermas insere a sua razão comunicativa, faz-se também necessário um atalho pela filosofia política de Espinosa, para que reencontremos a filosofia de Negri e possamos acompanhar seus desdobramentos conceituais.

De partida, é preciso atentar para uma concepção ontológica que, em Espinosa, rebaixa o lugar da razão tal como víamos na linhagem Kant-Hegel-Habermas. Não há primado da razão, seja esta pensada como atributo subjetivo, como processo histórico ou como pressuposto formal das práticas comunicativas e da sociabilidade. Com efeito, o homem de Espinosa caracteriza-se por um conflito interno permanente entre paixôes. Sendo o homem mais facilmente conduzido pelo desejo cego do que pela razão (ESPINOSA, 1973, p. 316), é preciso pensar, assim, a política não como consequência racional da associação humana, mas antes por sua imersão em um conflito passional constituinte. A ilusão teleológica dos filósofos residiria, para o holandês, no conceber a razão como fundamento da política, projetando nela a imaginação do que seriam os homens e as formas políticas se o homem racional preponderasse: "[...] aqueles que se persuadem ser possível levar a multidão, ou os homens ocupados com os negócios públicos, a viver segundo os preceitos da Razão, sonham com a idade de ouro dos poetas, isto é, comprazem-se na ficção" (ESPINOSA, 1973, p. 314). Retenhamos, deste ponto, a caracterização da ilusão teleológica enquanto erro racionalista, pois no contraste com Habermas poderemos ver uma maneira distinta de se distanciar de teleologias ilusórias.

Para Espinosa, a essência do homem, em vez de refletir a placidez da potência racional, é marcada sobremaneira pelo conatus, termo que distingue sua 
natureza conflituosa na busca por perseverar na existência. O homem, antes mesmo de colidir seus desejos e pulsões com os de outrem, é internamente constituído de múltiplos desejos e afecçóes que estão permanentemente em rota de colisão. O indivíduo é concebido como singularidade complexa (CHAUÍ, 2003, p. 307), cuja multiplicidade interna de paixões recoloca na constituição do humano a ideia fundamental de Espinosa de pensar a natureza e todas as coisas como manifestaçóes da "irrupção da multiplicidade no seio da unidade".

$\mathrm{Na}$ polêmica dirigida por Espinosa à tradiçáo teológica, rompe-se, por um lado, com a noção de transcendência ou exterioridade, intrínsecas à noção de um Deus mistificadamente concebido como ente volitivo, tal qual o homem. Por outro lado, denuncia-se também a atribuição de uma relação de causalidade final entre Deus e a natureza, pois assim como náo há exterioridade, não se pode tampouco conceber a natureza como fim desejado, finalidade calculada. Definindo, assim, um Deus coextensivo à natureza e o primado necessário da causalidade eficiente como motor fundamental da vida, Espinosa traça, ainda que metafisicamente, um plano radical de imanência, em que a liberdade dos homens pode ser identificada com a necessidade, uma vez que estão também inseridas no todo da causalidade eficiente divina.

Retirando, assim, Deus de uma posição de soberania distante perante o mundo, Espinosa pode banir o argumento teológico em suas pretensóes de autoridade. Com a fórmula "Deus sive natura" pode emergir, portanto, uma concepção imanente de liberdade, em que não são fórmulas transcendentais que descem ao mundo para conformá-lo ao bom e ao justo, mas antes é no próprio mundo imanente dos homens que os princípios éticos se definem. Nas palavras de Negri, atinge-se assim "um horizonte total que náo reconhece mais nem mesmo transcendência lógica. $\mathrm{O}$ divino é o conjunto da força potencial. Aqui o pensamento de Spinoza se fez inteiramente pensamento de superfície" (NEGRI, 1993, p. 178).

Curiosamente, o problema de uma sociabilidade marcada pela potência desregrada de sujeitos conflituosos em si mesmos se resolve para Espinosa via comunicação. Para além do choque das paixões entre si e destas com a razão no interior do conatus-cupiditas do sujeito, o filósofo holandês concebe o consenso como possibilidade intrínseca da sociabilidade e, assim, a democracia pode se 
afirmar como o governo absoluto sem recair na guerra de todos contra todos hobbesiana: "O espírito dos homens é, com efeito, demasiado obtuso para tudo poder penetrar de uma vez; mas deliberando, escutando e discutindo, afina-se e, à força de tatear, os homens acabam por encontrar a solução que procuravam e que tem a aprovação de todos" (ESPINOSA, 1973, p. 366).

Enquanto sujeito metafísico de Espinosa, herdado pela filosofia de Antonio Negri, a multidáo apresenta-se como sede, a um só tempo, de conflito e consenso. Há um pressuposto ontológico forte segundo o qual os homens são naturalmente talhados para alcançar o entendimento mútuo. E esta pressuposição dá, também, fundamento à filosofia política de Negri - a despeito de sua maior ênfase no antagonismo constitutivo do social. No entanto, é mister reconhecer que, diferentemente de Habermas, há uma tal inter-relação entre desejo (cupiditas) e razão para Negri que sua própria dissociação se torna problemática.

Assim como a filosofia espinosana faz romper com algumas dicotomias caras ao pensamento filosófico tradicional, nublando as distinçóes entre o uno e o múltiplo, a necessidade e a liberdade, o divino e o natural, a causa e o efeito, também parece que a divisória entre as paixôes, a volição subjetiva, e a razão deixam de ser definitivas. Como o próprio Negri atesta, "[...] na razão, inteligência e vontade se identificam, não existe ideia que não seja um ato de afirmação ou de negação" (NEGRI, 1993, p. 182).

Para além da autonomia da razão, é possível, ainda, desmistificar a autonomia do político, fazendo-o retornar ao interior de um plano de imanência em que a cupiditas da multidão e suas necessidades naturais são o único motor produtivo. Herdando, enfim, uma ontologia da crise da matriz espinosana, Negri pode aproximar a multidão de uma noção de poder constituinte como potência imanente do corpo social. Não há, contudo, qualquer vestígio de uma racionalidade universalista tal como em Habermas; para o filósofo italiano, com efeito, a constituição do social, em sua autodefinição ética, independe do momento transcendente que a necessidade de validade universal representa para a ação comunicativa. Antes, "[...] a constituição do social é uma potência baseada na ausência, isto é, no desejo, e o desejo nutre, incansável, o movimento da potência” (NEGRI, 2002, p. 26). 
Neste estudo, é importante, para nossos fins comparativos, atentar que, assim como em Espinosa, o direito equivale à potência e, dessa maneira, temos um horizonte de imanência completamente aberto, também em Negri a subsunção da racionalidade no interior da relação multidão-potência aponta para a irresolução de um mundo ético-político cuja expansividade é (i)limitada ao sabor do desejo da multidão. Em suas próprias palavras:

A forma da racionalidade, em sede ontológica, torna-se, pois, a relação entre potência e multidão. É na trama desta relação que a racionalidade é formada e desenvolvida, é sobre esta relação que a sua determinação substantiva adquire validade formal - ou seja, fundamento, eficácia, e também validação abstrata. (NEGRI, 2002, p. 452).

Delineia-se, pois, pelas duas perspectivas aqui investigadas, tanto a de Negri como a de Habermas, uma concepçáo do político que rejeita a necessidade de transcendência, tomando o consenso como possibilidade sempre presente das relaçóes sociais. Não à toa, a figura de Carl Schmitt aparece para ambos como adversário teórico comum; a totalidade ética não precisa de uma soberania alheia capaz de decidir em momentos de exceção, pois traz no seu interior a própria potência constitutiva de um político erroneamente tido por autônomo. É possível, no entanto, lermos este embate comum contra a filosofia política de Carl Schmitt ressaltando as diferenças marcantes de cada oposição. Por essa via, nota-se que Habermas se afasta em um duplo sentido da política decisionista de Schmitt: primeiro, por inscrever a razão comunicativa no interior da política e, assim, minar uma compreensão irracionalista baseada em decisóes desfundamentadas do soberano. Segundo, por se opor ao transcendentalismo da soberania schmittiana que abandona, em prol da facticidade da coerção política, o seu outro polo constitutivo, da validade. Para Negri, a querela se dá principalmente pela concepção do jurista alemáo que exterioriza a soberania da potência da multidão, e impóe um hiato entre potência e poder.

Esta remissão negativa de ambos à teoria da soberania de Schmitt nos revela a distância significativa que ambas as teorias, de Negri e Habermas, guardam entre si, no que diz respeito à constituição da imanência do político no social. À incidência necessária da razão comunicativa na construção habermasiana de uma totalidade ética se contrapóe, com Negri, a imagem de uma sociedade impulsionada em sua constituição pelas necessidades e desejos ima- 
nentes de um sujeito político, a multidão, formado pela convergência não homogeneizante das singularidades. $\mathrm{O}$ momento da validação, que aparece em Habermas como conformação do consenso a um critério da universalidade que lhe assegura resultados justos, não aparece na teoria de Negri. Tal validação, que vincula o consenso contextualmente alcançado com a sua viabilidade transcendente, aparece, antes, como forma, coercitiva em sua relação com o conteúdo, no imanentismo radical de Negri. "O terror e não a liberação: tal é o resultado que o racionalismo moderno determina quando se sobrepóe ao desenvolvimento ontológico do poder constituinte" (NEGRI, 2002, p. 438). Mesmo que a razão comunicativa esteja, para Habermas, embutida na própria tessitura social da modernidade, a filosofia de Negri parece náo admitir formalismos por sobre o conteúdo desejante da multidão.

A legitimidade das formas políticas, para Negri, localiza-se não nesta forma em si, mas no conteúdo produtivo que a torna real. A potência é ilimitada, deve ser ilimitada, para a democracia absoluta espinosana. E a selvageria anômala que decorre dos entrecruzamentos de um pluriverso de cupiditas espontâneas parece, pois, canalizar-se naturalmente para o bem comum. Frente a este naturalismo da democracia negriana, o formalismo racionalista de Habermas pode parecer uma artificialidade opressora, e náo libertadora. Mas se admitimos que Habermas pode, sim, (e deve) ser entendido em uma chave imanentista, é precisamente porque em sua teoria a razão, situada nas relaçóes de intersubjetividade, recusa a função de prescrever a priori as formas de sociabilidade; estas devem ser definidas, exclusivamente, pelos indivíduos democraticamente integrados. A razão procedimental, portanto, se mantém imanente ao contexto das práticas cotidianas, tal como a racionalidade negriana é endógena ao processo criador de sociabilidade do poder constituinte. Guarda, contudo, a sua particularidade com relação aos desejos e às vontades dos indivíduos; e é precisamente a submissão em Negri da razáo à cupiditas que constitui o ponto de afastamento decisivo de sua teoria em relação à de Habermas.

\section{Direito e Democracia: entre a norma e a anomalia}

"Numa era em que a política foi totalmente secularizada, o estado de direito não pode existir, nem ser mantido, sem uma democracia radical".

(Jürgen Habermas) 
"A liberdade, a verdadeira, a plena liberdade, aquela que amamos e pela qual vivemos e morremos, constrói diretamente o mundo, imediatamente. A multiplicidade não é mediatizada pelo direito, mas pelo processo constitutivo: e a constituição da liberdade é sempre revolucionária".

(Antonio Negri)

Como vimos, se Habermas e Negri se aproximam no movimento comum de inscrição da política em um campo de imanência, em que o Estado passa a ente subordinado de um político imerso no campo social, por outro lado é preciso atentar para a dissonância induzida pela particularidade com que fundamentam este imanentismo. Entre o desejo e a razão comunicativa, portanto, haveria uma considerável distância de premissas e repercussóes conceituais que conviria analisar. Uma vez inquiridos os fundamentos de seu arcabouço teórico, precisamos, pois, nos voltar neste ponto para a maneira como suas noçóes de democracia se distinguem entre si, na esteira daquela distinção fundamental já verificada.

O legado espinosista de Negri o impulsiona, com efeito, para além da noção de democracia como forma de governo. Se "a recusa do próprio conceito de mediação está na base do pensamento spinozista” (NEGRI, 1993, p. 190), há também que se notar a continuidade desta recusa no cerne da filosofia política de Antonio Negri. Pois na medida em que se toma a democracia como conteúdo básico da sociabilidade, a sua formalização em quaisquer canais fixos de manifestação aparece como estrangulamento indevido, como mecanismo asfixiador da potência.

Em termos espinosistas, quando se toma a potência em seu caráter ilimitado, o poder passa a ser entendido como obstáculo da democracia assim que não se subordine à potência da multidão. Da distinçáo potentialpotestas, emerge uma noçáo de democracia que exige, para ser absoluta, a superação do poder em prol da potência. Há que se lembrar, ainda, que em Espinosa o direito é coextensivo à potência. Nesse sentido, não há, nesta perspectiva, um direito que se imponha do exterior à potência, limitando ou mesmo interferindo no livre manifestar da cupiditas da multidão. O direito natural, em Espinosa, é ilimitado e se reflete na imediatez de uma potência que se regra a si mesma.

Abre-se, assim, o caminho para uma concepção de democracia antagônica com relação ao direito, concebido como formalização. É a partir daí que 
a narrativa negriana pode se constituir como o enredo sobre a trajetória de um poder constituinte que se impóe, teórica e praticamente na história da modernidade, contra e a despeito das investidas formalizadoras de aparatos e concepçóes jurídicas. Sigamos, pois, Negri em sua construção do que chama de paradigma do poder constituinte ${ }^{4}$.

Desde logo, é preciso atentar para o teor agonístico desta concepção: o poder constituinte, entendido como "poder que surge do nada e organiza todo o direito" (NEGRI, 2002, p. 9), trava perenemente uma relação tensa com a constituição que supostamente ele mesmo enseja. $\mathrm{O}$ plano de imanência onde Negri aloca o poder constituinte está, pois, constantemente fazendo referência àquele seu objeto por excelência, a constituição, ao passo que, por sua vez, o poder constituído (objeto), necessariamente transcendente com relação ao sujeito, sempre se coloca como empecilho para o absoluto da potência. A partir desta ambivalência, em que o objeto parece se contrapor ao sujeito de que desde o início depende, o poder constituinte se coloca como conceito em permanente crise.

Frente ao desejo fundamental da multidão, não há fundação possível que desloque sua condição de elemento essencial e determinante necessário da política. Nesse sentido, então, vemos Negri acompanhar tanto a noção marxiana de democracia como verdade de todo o regime político quanto a concepção espinosana segundo a qual a democracia é o critério de todas as formas de governo. A crise do conceito advém, pois, da complexa relação entre um conteúdo essencialmente anômalo e a forma de cristalização deste conteúdo que, no momento mesmo em que reflete a potência, aparece sempre e desde já como exterior e, assim sendo, como negação da própria potência.

A abertura para a anomalia prescinde da norma para se fazer efetiva; como vimos, trata-se de uma noção de política para além de mediaçóes, que traz a democracia para o nível da imediatez do desejo constituinte:

Da crise do conceito de poder constituinte ao conceito de poder constituinte como crise: justamente porque é crise, a potência constitutiva é uma radical fundação subjetiva do ser,

4 "O paradigma do poder constituinte é aquele de uma força que irrompe, quebra, interrompe, desfaz todo equilibrio preexistente e toda continuidade possivel. O poder constituinte está ligado à ideia de democracia, concebida como poder absoluto" (NEGRI, 2002, p. 2I). 
é a subjetividade da criação. Uma criação que nasce da crise e, assim, uma criação que nada tem a ver com a linearidade da racionalidade moderna, nem com a utopia. (NEGRI, 2002, p. 441$)$.

Com o paradigma do poder constituinte, a pretensão de objetividade é rechaçada por completo, já que a subjetividade criadora não percorre qualquer trilha definida a priori - o que conduz Negri para um campo oposto àquele do universalismo pragmático habermasiano. Se, para Habermas, a razão se impóe ao desejo como forma pressuposta em um processo de construção democrática que necessariamente passa pela comunicação visando ao entendimento, para Negri, por seu turno, é preciso libertar o desejo de quaisquer pressupostos universais. O problema de Negri é, entâo, posto por ele mesmo da seguinte maneira:

[...] que Habermas, sua filosofia morna e seu transcendentalismo lânguido resultam ineficientes, está claro; mas, como entender, definir, descrever a riqueza criadora do princípio constituinte? Como fazê-lo de modo a evitar ser enredado nas delicadas malhas da filosofia da comunicação ou ser paralisado por uma síndrome conservadora?. (NEGRI, 2002, p. 34).

Buscando ultrapassar este conservadorismo que vincula à filosofia política habermasiana, Negri opóe de maneira aparentemente decidida a democracia e o seu sujeito-chave, a multidáo motriz do poder constituinte, ao direito e à soberania. Mas a rejeição destes momentos supostamente transcendentes com relação ao radicalismo da imanência de sua democracia traz ruídos internos ao seu próprio aparato conceitual.

Aqui, pensar a soberania, ou o direito, como transcendente constitui encaminhamento que se volta contra sua própria definição radical do plano de imanência. Pois, se este se define pelo entrelaçamento entre político e social, torna-se problemática tal exteriorização (rumo à transcendência) de uma estratosfera política que pairaria por sobre os desejos e pulsôes socialmente enraizadas. Nesse sentido, Negri parece inverter aquela própria noção foucaultiana de um político alheio ao que chama de "modelo da soberania"; noçáo esta que, em uma primeira leitura, constitui fonte teórica, ao lado de Espinosa e Marx, para a definição de seu imanentismo.

Vejamos, brevemente, a forma como Foucault formula sua crítica ao modelo da soberania para, em seguida, entendermos a reviravolta que, em certo 
sentido, deixa Negri aquém do próprio imanentismo foucaultiano. Importa, ainda, atentar para os elementos pós-estruturalistas herdados pela filosofia de Negri e com relação aos quais Habermas fará questão, como se sabe, de se distanciar.

É no curso proferido em 1976 no Collége de France, publicado sob o título de Em defesa da sociedade, que Michel Foucault diretamente articula sua crítica ao que denomina modelo da soberania. Sem a pretensão de adentrarmos nos detalhes da argumentaçáo foucaultiana, podemos ver quatro pontos centrais sobre os quais sua crítica incide, quais sejam: as noçóes de contrato, sujeito, verdade e opressão. Antes de tudo, para Foucault, uma análise política em termos de soberania atenta para um momento fundador (heurístico ou não), a partir do qual se erige a comunidade política: momento do contrato. Tomar o contrato como ponto de partida implica náo apenas pensar na divisão natureza/sociedade e em um estado de natureza acessível à razão; resulta, ainda, em uma análise cujo objetivo primordial é identificar a maneira pela qual se pôde constituir um soberano indivisível, a partir da multiplicidade de indivíduos e vontades (FOUCAULT, 1999, p. 34).

Este modelo da soberania é, sempre segundo Foucault, essencialmente um modelo jurídico, na medida em que toma o poder como direito original. Trata-se, por esse ângulo, de entender o poder enquanto atributo constitutivo do homem enquanto tal, do homem em estado de natureza. Poder-atributo, cuja concessão inauguraria a ordem política: "O velho sistema que vocês encontram nos filósofos do século XVIII se articularia em torno do poder como direito original que se cede, constitutivo da soberania, e tendo o contrato como matriz do poder político" (FOUCAULT, 1999, p. 24). Pensa-se, pois, a política através de um binário legitimidade/opressão, o que significa repartir o terreno político entre os atos soberanos condizentes com o contrato firmado, portanto legítimos, e aqueles que ultrapassam os limites do contrato, impondo aos contratantes uma força opressiva. A centralidade do contrato nessa partilha entre o legítimo e o ilegítimo supóe a preexistência de um consenso fundador. Consenso este que balizaria a "ideia de um corpo social constituído pela universalidade das vontades” (FOUCAULT, 2000, p. 146).

Há, ainda, nessa perspectiva, a pretensão de fundar a sociedade sobre algo que seria uma verdade primeira. Verdade que o contrato buscaria estabelecer 
e perpetuar; verdade que limita os excessos do poder. Nesse sentido, a questão tradicional da filosofia política de acordo com Foucault diz respeito a certo arranjo do triângulo poder-direito-verdade (FOUCAULT, 1999, p. 28). Pondo a verdade como princípio, a teoria da soberania instrumentaliza um poder que serve de meio à ordem jurídica. Veremos adiante como Foucault organiza um triângulo totalmente diferente a partir dos mesmos três elementos. Por ora, ao nos atermos à demarcação do quadro geral do modelo da soberania, devemos ressaltar como ela lida com a noção, táo problematizada em toda a obra de Foucault, de sujeito. Náo apenas a verdade é posta no princípio da ordem política, ao lado do poder tomado como atributo. $\mathrm{Na}$ medida mesma em que assim se entende o poder, pressupóe-se, de antemão, um sujeito anterior. Dessa pressuposição, Foucault parte para afirmar que "[...] a teoria da soberania tenta necessariamente constituir o que eu chamaria de um ciclo, o ciclo do sujeito ao sujeito" (FOUCAULT, 1999, p. 49), em que o primeiro é o ser dotado de atributos naturais e o segundo é o sujeitado na relação de poder - o súdito. Outra questão básica da filosofia política, que, no entender de Foucault a rege em suas análises, emerge neste ponto: como estabelecer uma passagem legítima entre o sujeito natural e o sujeito social?

Em uma entrevista concedida a Jacques Rancière um ano após o curso que estamos seguindo, Foucault vai assinalar o caráter negativo que o poder assume nos parâmetros da soberania. A partir do momento em que se supóe um homem natural dotado de um poder-atributo ao qual se renuncia no momento do contrato, a atuaçáo do poder no estado de sociedade ganharia um contorno essencialmente negativo:

Para dar conta do exercício da soberania se supõe seja a renúncia aos direitos naturais, seja o contrato social, seja o amor do senhor. Do edifício construído pelos juristas clássicos às atuais concepções, parece-me que o problema é sempre apresentado nos mesmos termos: um poder essencialmente negativo que supõe, de um lado, um soberano cujo papel é o de interditar e, do outro, um sujeito que deve, de uma certa maneira, dizer sim a essa interdição. (FOUCAULT, 2003, p. 247).

Deste interlúdio foucaultiano em nossa análise, pode-se ressaltar que, em seu repúdio tipicamente pós-estruturalista às noçóes de sujeito, verdade e adjacências, um ponto central para o qual converge sua concepção diz respeito, principalmente, à recusa de uma concepção do poder em chave negativa. 
Ou seja, o modelo que Foucault opóe ao modelo da soberania, um modelo marcadamente nietzscheano de batalhas perpétuas, visa precisamente a retirar o elemento transcendente de um poder que, a seu juízo, está necessariamente embutido nas práticas sociais mais diversas. É, pois, no sentido da construção deste plano de imanência totalizador que Foucault teoriza, seja a disciplina em Vigiar e Punir (1975), seja a hipótese repressiva (prima-irmã do modelo da soberania), tratada no primeiro volume de sua História da Sexualidade (1976).

Negri reconhece e admite o seu débito com relação ao legado foucaultiano, mas ao mesmo tempo insiste em ressituar a soberania como um poder constituído mais além da imanência foucautiana. Se, por um lado, Negri pode interpretar como "o cerne brilhante" da análise de Foucault a insistência no fato "[...] de que o exercício da disciplina é absolutamente imanente às subjetividades sob seu comando" (HARDT; NEGRI, 2001, p. 351); por outro lado, ele náo pode aceitar sem restriçốes esta definição de um imanentismo do poder que obstaculiza a referência a qualquer sujeito com atributos anteriores ao poder. $\mathrm{Na}$ medida em que o poder constituinte, em Foucault, reside nas próprias lógicas internas aos padrôes de sociabilidade, com relação aos quais qualquer anterioridade é tratada como impureza metafísica, Negri precisa achar uma fórmula que compatibilize a herança foucaultiana com a herança espinosista de um sujeito metafisicamente formulado como anterior a toda e qualquer ordenação. E, neste caminho, pode-se apontar para a equívoca definição de um político que, a despeito da radicalidade imanentista herdada tanto do filósofo holandês seiscentista quanto do francês pós-estruturalista, permanece descrito como campo de oposição entre poder constituinte e o poder constituído.

Nesse sentido, Negri principia por questionar o método foucaultiano, cuja ênfase estruturalista na sincronia o impediria de localizar o sujeito agente do processo político em chave diacrônica ${ }^{5}$ E termina por inverter a própria

5 "Não parece, entretanto, que Foucault - mesmo quando apreendeu vigorosamente o horizonte biopolítico da sociedade e o definiu como campo de imanência - jamais tenha tido êxito em afastar seu pensamento da epistemologia estruturalista que orientou sua pesquisa desde o início. Por epistemologia estruturalista queremos dizer a reinvenção de uma análise funcionalista no domínio das ciências humanas, um método que efetivamente sacrifica a dinâmica do sistema, a temporalidade criativa de seus movimentos, e a substância ontológica de reprodução cultural e social. De fato, se nessa altura tivéssemos de perguntar a Foucault quem ou o que impele o sistema, ou melhor, o que é o 'bios', sua resposta seria inefável, ou não haveria resposta" (HART; NEGRI, 200I, p. 47). 
noção de biopoder de Foucault, que passa a ser entendida como um poder alienador da subjetividade, anterior e oprimida em seus impulsos, de onde se originaria a vitalidade do sistema.

É importante para nossa análise verificar esta ressignificação dos termos foucaultianos, na medida em que ela baseia todo o método de investigação histórica de Negri e Hardt em seus escritos em conjunto. No corpo da obra de Michel Foucault, mais precisamente daquela escrita na última metade da década de 1970, a análise perde sua anterior ênfase no discurso e nos saberes e passa a focar nos regimes de poder, com destaque para a emergência de uma nova lógica de relaçóes de poder no século XIX, paralela ao desenvolvimento capitalista. Desta nova lógica, Foucault depreende três categorias fundamentais: biopoder, biopolítica e disciplina. $\mathrm{O}$ biopoder é o nome geral creditado à novidade de um regime baseado não mais na ameaça da vida ("fazer morrer e deixar viver"), mas na constituição da própria vida, individual e social, nos seus mais capilares registros ("fazer viver, deixar morrer"). Já a biopolítica e a disciplina seriam duas de suas modalidades: a primeira diz respeito aos mecanismos gerais de controle populacional, situando-se no nível do Estado e tomando como objeto a população, enquanto a disciplina representa a penetração do poder nos interstícios das mais variadas relaçóes sociais e na própria constituição de individualidades.

Podemos, pois, interpretar Vigiar e Punir como uma das mais elaboradas descrições do que o próprio Foucault gostava de chamar de "face oculta das Luzes": no subsolo da ilustração e do progresso da razão, ou antes, como campo efetivo de imanência, o que Foucault encontra é uma forma de dominação tanto mais insidiosa quanto menos se pode encontrar um lado de fora a ela. A imanência do biopoder representa, enfim, uma nada idílica relação de poder totalizante, em que súdito e soberano se alternam e se misturam nos mesmos corpos dóceis e vigilantes.

Se Habermas responde à afronta foucaultiana remetendo a elementos não explorados, internos ao plano de imanência tão caro a Foucault, Negri, por sua vez, parece recusar este sombrio horizonte por meio de um retorno, certamente náo proposital, ao modelo de soberania rejeitado por Foucault e, paradoxalmente, por ele mesmo. 
Enquanto o próprio conceito de soberania representa o avesso da democracia para Negri (2002, p. 49), é possível pensar também o biopoder como rubrica de um poder parasitário com relação a uma esfera biopolítica que agora passa a ser tomada no eixo positivo ao lado do poder constituinte, como esfera imanente de produçáo criativa da vida social. Nesse sentido, tornam-se latentes os problemas conceituais que advêm da (in)compatibilização entre o radicalismo imanentista e uma noção de democracia exterior ao direito. E, do estabelecimento de uma distinção entre direito e democracia, advêm outras consequentes distinçôes entre potência e poder, multidáo e soberania, anomalia e norma, as quais terminam por minar a própria intenção primeira de recusa de quaisquer transcendentalismos exteriores ao registro do social.

Foucault define sua imanência de maneira talvez mais coerente com seus princípios: o direito não é exterior às práticas constitutivas de sociabilidade, ao contrário, nasce e permanece no próprio seio das relaçôes sociais. Recusando, pois, uma noção negativa de poder - tão bem exposta na sua análise da funcionalidade da hipótese repressiva para a reprodução de uma dominação sem sujeitos -, Foucault pode concebê-lo positivamente à custa da emancipação, que em sua teoria ganha um suporte pouco definido na noção de resistência. Para Foucault, não há sujeitos transcendentais como em Kant, tampouco uma história redentora como em Hegel, mas antes uma lógica de poder imanente e totalizante, que abarca os mais recônditos registros da vida social e cuja dinâmica funciona como segunda natureza.

Como Negri objetiva, a um só tempo, evitar o estruturalismo (negativista) deste plano de imanência - para o qual a esperança democrática deve ceder terreno a uma noçáo de liberdade estetizante e individualizada - e definir positivamente uma imanência, sem apelo à razão, a partir da qual possa criticar, em chave democrática, a história da modernidade, restam-lhe as noçôes, aparentemente ambíguas, de imanência e do poder constituinte.

Assim, o poder constituinte tanto pode ser definido como "a ausência, o vazio, o desejo" que "são o motor da dinâmica político-democrática enquanto tal" (NEGRI, 2002, p. 27), quanto ainda como a "negação mais radical e profunda, mais desesperada e feroz" (NEGRI, 2002, p. 36). A exterioridade do poder com relaçáo à potência, certamente embaraçosa para um foucaultiano, é afirmada de maneira ainda mais enfática, em seu tratado sobre o Império, 
como nova forma da soberania pós-moderna: "Com efeito, a relação que o governo imperial impóe à virtualidade da multidão é simplesmente uma relação estática de opressão” (HARDT; NEGRI, 2001, p. 382).

Aqui, o risco de pensar a metafísica como "a verdadeira ciência política da era moderna” (NEGRI, 2002, p. 423) revela-se em uma noção de multidão que figura como sujeito primordial da política negriana. Não mais, por decerto, o sujeito kantiano transcendental implodido desde Hegel a Habermas, mas agora um sujeito imanente cuja posição soberana na história remete, de certa maneira, tanto à filosofia da consciência kantiana quanto à filosofia da história hegeliana. Não mais o sujeito dotado de uma razão universal, agora se trata de um "sujeito composto desejante", cujos múltiplos desejos convergem, por necessidade (e, logo, por liberdade), ao bem comum. Na análise histórica de Negri e Hardt, transparece a cumplicidade lógica entre a aproximaçáo hegeliana do par efetivo/ racional e a identidade espinosista entre liberdade/necessidade. Nesse sentido, podemos ler que o poder constituinte não é mera formulação conceitual-normativa, e sim um instrumento descritivo da história factual da modernidade: “[...] toda a história moderna foi caracterizada pela indistinção entre o social e o político no exercício do poder constituinte por parte das classes subordinadas" (NEGRI, 2002, p. 375). O filósofo italiano observa, ainda, que o capitalismo moderno "[...] conduz o conceito de poder constituinte ao seu pleno desenvolvimento, construindo-o como força que penetra a sociedade inteira, como poder social expansivo que absorve e modela qualquer outro poder, e o estatal acima de tudo" (NEGRI, 2002, p. 355).

É curioso notar, portanto, que a filosofia política de Negri, tal como a analisamos aqui, recaia precisamente naquelas armadilhas filosóficas que o próprio Habermas sublinha como inauguradoras da modernidade: tanto em um subjetivismo com resquícios metafísicos, quanto em uma noção de história hegelianamente redentora (KURZ, 2003, p. 93).

O democratismo radical de Negri mostra-se ambivalente no que diz respeito à construção de um plano de imanência que resulta parcial-pois requer a exterioridade opressora do direito e da soberania - e metafísico - pois conta com um sujeito trans-histórico e com uma história já não tão événementielle quanto Foucault gostaria. Compete-nos, por ora, identificar a maneira como Habermas, por seu turno, relaciona direito e democracia de maneira a 
não mais precisar evocar aquela problemática exterioridade, conceituada por Negri, entre norma e anomalia.

A esta altura, a contraposição entre as duas filosofias políticas, de Negri e Habermas, se revela tanto mais interessante quanto mais podemos observar a formulação habermasiana conceituar, de modo certamente diverso, um conjunto de noçôes que, não obstante, parecem caras a ambos os autores. Ora, se em Negri a imanência esbarra na metafísica da multidão e se o conteúdo agonístico de sua democracia arrefece com uma concepção histórica subjetivista e teleológica, em Habermas, por outro lado, podemos ainda depreender uma busca pelo fundamento crítico da democracia via plano de imanência concebido, agora, em outros termos, os da razão comunicativa. Isto leva, por decerto, Habermas a um horizonte conceitual significativamente diferente.

A partir, então, de breve recapitulação acerca desta imanência habermasiana, poderemos avançar na análise rumo aos conceitos principais que fundam a relaçáo entre direito e democracia no âmbito de sua teoria. De partida, há que se destacar certa ambivalência inscrita na própria construçấo de um plano de imanência quando este parte da noção de razão comunicativa. Em sua pragmática universal, ao buscar a reconstrução do plano genérico de validade do discurso, Habermas concebe os pressupostos universalistas de todo e qualquer ato de fala voltado ao entendimento. Desse universalismo, depreende-se, em um nível, uma validade que se aloca no plano suprasubjetivo (HABERMAS, 1979 , p. 4), pois reflete a conformação a parâmetros transcendentes com relação ao contexto; em outro nível, porém, o reconhecimento da validade de uma assertiva necessariamente se situa no plano intersubjetivo, já que "[...] porque ninguém tem acesso direto a condiçôes de validade não interpretadas, a 'validade' deve ser compreendida em termos epistêmicos como 'validade provada para nós”' (HABERMAS, 1998, p. 14).

Aqui, na própria estrutura da ação comunicativa, já se pode entrever a formulação de um binômio caro à análise habermasiana da democracia e do direito, qual seja, aquele que envolve validade/facticidade. $\mathrm{O}$ consenso, sempre situado, traz consigo a compatibilidade com parâmetros universais que é, em última análise, o que assegura sua facticidade. Nesse sentido, Habermas pode falar de uma transcendência do interior e, nublando assim a divisória entre o universal e o particular, constrói o que chamamos até aqui de plano de 
imanência por sobre esta ambivalência. Esta imanência não remete, como a de Negri, a um sujeito naturalisticamente dotado dos atributos condicionantes do consenso e da validade - náo é, ademais, à toa que este conceito nem aparece na teoria do italiano. Pois o automatismo da cupiditas da multidão na produção das relaçóes sociais não exige qualquer remissão a elementos que sejam externos a seus caracteres volitivos, seus desejos. Não se trata, evidentemente, para Habermas, de construir sua noção de democracia sobre tais bases voluntaristas. Para ele, as próprias relaçóes sociais apenas podem se travar na medida em que portam esta referência, quase sempre despercebida, ao plano de uma validade transcendente e imanente a um só tempo.

The idealization built into truth claims confronts us with the more ambitious task of explaining, in terms of the pragmatic conditions of argumentation, how the validity claims raised hic et nunc and aimed at intersubjective recognition or acceptance can, at the same time, overshoot local standards for taking yes/no positions, that is, standards that have become established in each particular community of interpreters. (HABERMAS, 1998, p. 15).

Nunca é demais lembrar que a lógica da ação comunicativa não consta de um leque de opçóes passíveis ou não de serem escolhidas por uma comunidade; trata-se, antes, de um enquadramento compulsório das açóes que visam o entendimento. Habermas não afirma "que os homens gostariam de agir de modo comunicativo", e sim "que eles são obrigados a agir desta maneira” (2005, p. 170). Dessa forma, aqui se abre o caminho para uma divergência crucial entre as democracias de Negri e Habermas. Pois, enquanto o primeiro a pensa como fundamento e consequência de uma agência subjetiva automaticamente voltada para a harmonia e o bem comum, este automatismo na consonância de fins autoimpostos ética ou individualmente não figura na teoria habermasiana. É curioso atentar para o fato de que é da teoria radical democrática de Negri, do alto de seu antiliberalismo, que pode advir uma noção tão harmoniosa de desejos e pulsóes que se complementam por si mesmos - noçáo esta que exibe, a contragosto, ecos de uma mão invisível, precariamente alojada, no interior de uma teoria soi-disante revolucionária.

Evitando esta armadilha do automatismo, a reconstrução de Habermas lida com pressupostos diferentes e faz apelo a um elemento universalista que é princípio pressuposto da comunicação e não consequência necessária do choque de desejos. Da dualidade transcendência/contexto, somos conduzidos pela 
teoria habermasiana a outros binômios centrais, referentes à diferenciação entre moral e ética e, ainda, entre valores e normas.

Neste ponto, deixa-se entrever o decisivo afastamento de Habermas com relação às concepçóes pós-modernas ou nietzscheanas do político. Seja no modelo de batalhas perpétuas de Foucault (1999, 2000), seja na ontologização da relação amigo/inimigo por Schmitt (1992), em ambas as formulações transparecem os resíduos de uma ontologia da vontade de poder que pouca margem dá ao conceito de democracia. Em Schmitt, especialmente, o pluriverso político é formado por comunidades éticas cuja soberania interna se relaciona diretamente com a distinção e a inimizade com o exterior. Ora, para Habermas, a democracia náo pode sequer ser concebida em um horizonte conceitual que, no limite, torna impossível o consenso. A possibilidade do consenso exige um plano de referência que se situa para além das identidades éticas e de suas particularidades. A justificação, em uma modernidade pós-metafísica carente de autocertificação, requer o patamar universalista que, em Habermas, parece derivar da moralidade do imperativo categórico kantiano.

Tem havido uma crescente necessidade de justificação, a qual, sob as condições do pensamento pós-metafísico, só pode ser suprida por discursos morais. Estes visam a uma avaliação imparcial de conflitos factuais. Ao contrário das deliberações éticas, que são orientadas ao telos da minha/nossa própria boa vida, as deliberações morais requerem uma perspectiva liberta de todo egocentrismo ou etnocentrismo. (HABERMAS, 1988, p. 97).

A noção de boa vida deve, portanto, ceder terreno a concepçóes de justiça que requerem a condição de universalidade como pressuposto intrínseco. Recusar, para Habermas, este plano universalista como quimérico conduz ao niilismo de uma ontologia do poder tão estranha à democracia quanto afeita a determinações trágicas da história.

À ilusão teleológica de uma harmonização espontânea de interesses particularistas, Habermas opóe, então, a possibilidade de um consenso mais elevado, no plano da moral. Assim, relacionando-se ao plano da moralidade, a norma pode ser pensada náo como exterioridade com relação à anomalia negriana da multidão, mas antes como recurso endógeno de formação de consenso e de constituição de uma vida em comum. O que é valoração em Negri passa a ser "normatização" em Habermas. Normatização esta que, evidentemente, guarda pouca semelhança com o termo semelhante ("normalização") aplicado 
por Michel Foucault. Porque Foucault ignora a validade subjacente à produção normativa e se fixa apenas na sua facticidade modeladora de sociabilidade, sua análise pode tomar a norma (e o "normal”) em seu aspecto negativo, pois não há em seu arcabouço teórico qualquer possibilidade de universalismo para além do contexto. Para além desta autodeclarada filosofia da platitude, contudo, Habermas pode tomar a norma como elemento fundamental da democracia, na medida em que ela fornece o vínculo entre o particular e o universal de que carece uma definiçáo categórica de democracia.

Na oposição norma/valor, vê-se, pois, a dívida que a teoria de Habermas ainda guarda com o kantismo, uma vez que tal distinção reflete a dicotomia entre inclinação e dever. Enquanto o valor se orienta por açóes teleológicas e por uma racionalidade orientada para fins, a norma remete a uma regra compulsória. Assim, enquanto a validade da norma se define em termos binários, não podendo haver norma mais válida do que outra, os valores podem submeter-se a gradaçóes que variem com a inclinação do sujeito (HABERMAS, 1988, p. 255). Em uma palavra, ao relativismo de valores escalonáveis e intercambiáveis ao sabor da substituição de uma finalidade por outra, a norma opóe a objetividade como cláusula decisiva.

Com a inscrição da norma, via pragmática universal, no cerne das relaçôes comunicativas constituintes de sociabilidade, Habermas pode, enfim, conceber uma democracia internamente entrelaçada com o direito. Esta dependência intrínseca se articula em dois níveis: por um lado, a democracia exige conceitualmente o direito na medida em que Habermas os concebe como co-originários; por outro, a democracia exige faticamente o direito devido às implicaçôes empíricas observadas pela sociologia funcionalista adotada.

Para Habermas, em qualquer comunidade que vise a um arranjo democrático e horizontal onde todos possam igualmente participar das decisóes públicas, é necessário um sistema de direitos que nasce no momento mesmo em que a democracia se institui. Nesse sentido, a autonomia privada que assegura aos cidadãos as liberdades fundamentais para que tomem partido na decisão coletiva não é apenas funcional à autonomia pública; assim como a participação democrática não deve ser concebida como instrumento para a garantia das liberdades privadas. Ambas, além de requererem a outra para sua própria efetividade, são em Habermas indissociáveis. 
É neste ponto, pois, que a teoria do discurso da democracia habermasiana se pretende uma superaçáo teórica dos modelos liberal e republicano. Enquanto o liberalismo confere primado aos direitos individuais, tomando-os como garantias contra a intromissão indevida do poder público, o republicanismo funcionalizaria as liberdades privadas em prol de uma participação política prioritária. Entretanto, e este é talvez o ponto principal da argumentação habermasiana, o direito não precisa ser pensado como limite à democracia (tal como assevera Negri) e tampouco esta limita necessariamente o alcance dos direitos - porque, essencialmente, tanto a validade do direito necessita internamente da democracia quanto a facticidade da democracia requer a garantia da autonomia privada e de um sistema de direitos basilares.

Porque a vontade soberana do povo pode se expressar apenas na linguagem de leis gerais e abstratas, ela traz, diretamente inscrita em si, o direito de cada pessoa a liberdades iguais. [...] A vontade dos cidadãos é vinculada, através do medium de leis gerais e abstratas, a um procedimento legislativo que exclui per se todos os interesses não-generalizáveis e apenas admite regulações que garantam liberdades iguais para todos. De acordo com essa ideia, o exercício procedimentalmente correto da soberania popular assegura simultaneamente a substância dos direitos humanos concebidos por Kant. (HABERMAS, 1988, p. 101).

Uma vez que, para Habermas, "a chave normativa está na autonomia, e não no bem-estar” (HABERMAS, 1988, p. 418), sua concepção da co-originalidade afasta-se do modelo liberal, em que a controversa emancipação de uma racionalidade voltada a fins permanece presa a um individualismo e às desmistificadas premissas do funcionamento espontâneo do mercado. A autonomia náo pode ser pensada ora privada, ora publicamente, na medida em que os indivíduos mesmos não podem ser pensados ora isolados, ora em sociedade. Como são singularidades formadas na e formadoras da socialização, os indivíduos não podem ter estas duas faces de sua autonomia separadas, ao preço de a perderem por completo.

E porque a chave normativa reside na autonomia e não no bem-estar, Habermas constrói sua teoria da democracia com um sentido deontológico-procedimental, já que as definiçôes valorativas-teleológicas não podem ser prescritas com qualquer grau de objetividade pela teoria. $\mathrm{O}$ "socialismo" de Habermas, se assim podemos concebê-lo, pode ser entendido como mais formal e, ao mesmo tempo, como mais substantivo do que o de Negri. Mais 
formal, pois faz recurso às categorias universais de validade, moral e norma para fundamentar uma democracia que Negri situa, por sua vez, como processo do devir da multidáo. E mais substantivo, pois submeter a democracia às voliçóes da multidão não indica nenhum de seus possíveis aspectos, pois a vontade sem rédeas nesse caso se defronta apenas com o vazio de uma construção hipotético-volitiva. Enquanto em Habermas, o próprio recurso aos componentes universalistas nos parece pintar o quadro de uma democracia categórico-normativa cujo fundamento de igualdade e liberdade reside, para além dos desejos, sob a forma da lei. Em suas próprias palavras, se

[...] o socialismo é concebido como o conjunto das condições necessárias para formas emancipadas de vida sobre as quais os próprios participantes devem primeiramente chegar ao entendimento, então se reconhecerá que a auto-organização democrática de uma comunidade legal constitui o núcleo normativo deste projeto”. (HABERMAS, 1988, p. XLI).

Dessa auto-organização democrática, Habermas (1988, p. 136) deriva sua noção de que, devido à distribuição equitativa de um poder comunicativo a partir do qual a democracia se faz possível, "não pode haver um soberano no estado constitucional”. Habermas aproxima-se então de Negri na oposição entre democracia e soberania, não obstante os diferentes termos em que se coloca a distinção. Para Negri, a recusa da soberania refletia a renúncia ao direito enquanto poder constituído antagonista com relação ao poder constituinte democrático da multidão. Já para Habermas, atestar que não há soberano no estado constitucional implica, com efeito, uma horizontalidade dos processos decisórios e deliberativos que assegura a legitimidade do aparato legal.

É preciso, a esta altura, diferenciarmos legitimidade de validade, se não quisermos incutir na democracia habermasiana a atribuição de um excesso de racionalidade contra o qual o autor se previne. Não se trata, pois, de, concebendo a instância de moralidade como elemento universalista da constituiçấo democrática, derivar daí uma relação de identidade perfeita entre a moral e o direito.

Legitimidade, no vocabulário habermasiano, refere-se à capacidade de um ordenamento político de ser reconhecido. Para o autor, "[...] a exigência ou pretensão de legitimidade liga-se à conservação, no sentido da integração social, da identidade normativamente estabelecida de uma sociedade" (HABERMAS, 1983, p. 224). Nesse sentido, há que se tomar a moral como um dos componentes no processo formativo desta identidade normativamente 
estabelecida. Aqui, o elemento volitivo retorna à teoria de Habermas e o que era puro universalismo no âmbito da moral passa a ser um composto de interesses, valores e normas (HABERMAS, 1988, p. 156). Há que se considerar, todavia, que este composto de que se origina o direito náo se forma sem a preponderância do elemento universalista da moral. A despeito desta encarnaçáo de sua democracia nos interesses e valores preponderantes na comunidade legal, o componente universalista deve ter primazia para uma democracia que se quer categórica. Não à toa, Habermas fala em "domesticaçáo" para tratar da relação entre as normas e os interesses, em um movimento de franco afastamento daquela concepção volitiva à la Negri (HABERMAS, 1988, p. 226).

É falsa a imagem que caracteriza a democracia habermasiana como se ela se fundasse exclusivamente no potencial moral dos cidadãos: há que notar o movimento, caro à perspectiva reconstrucionista de Habermas, que vai da filosofia em direção à sociologia. Não apenas a democracia exige o direito conceitualmente como condição de sua efetividade, como também o direito se impóe como medium inabdicável nas condiçôes sociais complexas de que Habermas procura dar conta.

Alguns dos pressupostos da teoria dos sistemas de Luhmann levam Habermas a conceber a sociedade do capitalismo tardio a partir do descolamento e das particularidades de diferentes subsistemas. Especialmente os subsistemas econômico e administrativo ganhariam uma crescente independência com relação aos circuitos comunicativos do mundo da vida - e, frente a esta tendência, o direito figura para Habermas como único medium capaz de suportar o ônus integrativo imposto pela força centrífuga dos subsistemas luhmannianos.

Enquanto o mundo da vida permanece como locus de uma linguagem ordinária responsável pela solidariedade e pela manutençáo de laços integrativos, esta linguagem não é, contudo, por si mesma capaz de dirigir subsistemas quase autopoiéticos. Assim, é sociologicamente que se justifica, em Habermas, a necessidade democrática da mediaçáo via direito (HABERMAS, 1988, p. 56).

Retomando, enfim, o paralelo com Negri, é mister atentar que a democracia habermasiana, mesmo com sua remissão a componentes universalistas, não perde por isso seu caráter agonístico. Se, em Negri, o poder constituinte é formulado como conceito de uma crise, referente à tensão entre direito e democracia, também em Habermas a fundamentação da democracia no 
consenso se define pela crise, desta feita referente à abertura do processo constituinte para decisóes que apenas podem ser tomadas no interior do plano de imanência, sem referência possível à transcendência de um soberano ordenador. Admitir a fundamentação da democracia no consenso requer, como contrapartida, a abertura da possibilidade de dissenso, não obliterada na teoria de Habermas. No curso da evolução social narrada por Habermas, "[...] o risco do dissenso cresce na medida em que se expande o âmbito para adotar posiçóes sim/não a respeito de criticáveis alegações de validade" (HABERMAS, 1988, p. 25).

Este risco, inerente ao horizonte secularizado da política na modernidade, é hipostasiado na medida em que a integração social pode apenas derivar de uma ação comunicativa que não pode controlar mais a eclosão de dissensos sem ao mesmo tempo incrementá-la, tornando o discurso racional permanente (HABERMAS, 1988, p. 37) e fazendo da constituição um processo contínuo de realização democrática.

Chegamos, pois, a um quadro da democracia habermasiana segundo o qual o antagonismo negriano entre norma e anomalia passa a motor constitutivo das relaçóes sociais sob um estado democrático de direito. Não há exterioridade a ser resolvida; não é preciso que o poder constituinte dissolva o poder constituído e liberte as amarras que supostamente prendiam a multidão e sua cupiditas. A razão comunicativa, no que tem de universal, não uniformiza a pluralidade de opinióes, interesses e culturas sob uma única forma racionalmente condizente; pelo contrário, ela libera as forças potenciais de dissenso sem, contudo, abrir mão do resultado racional assegurado pelo procedimento democrático.

Se a soberania, comunicativamente fluida, dos cidadãos, se manifesta imediatamente no poder dos discursos públicos que emanam de esferas públicas autônomas e tomam forma nas decisões de corpos legislativos democráticos e politicamente responsivos, então o pluralismo de crenças e interesses não é suprimido, mas sim desencadeado e reconhecido pelas estruturas discursivas de comunicação pública. Essa razão [comunicativa] recusa-se a conceder que um consenso está livre de coerção, e então possui força legitimadora, a menos que o consenso devenha sob o proviso falibilista e sobre as bases de uma anárquica e irrefreada liberdade comunicativa. Na vertigem desta liberdade, não há qualquer ponto fixo para além do próprio procedimento democrático, um procedimento cujo sentido está desde já implícito no sistema de direitos. (HABERMAS, 1988, p. 186). 
Pode-se questionar, como o faz José Eisenberg (2003, p. 61), que a teoria de Habermas não consegue superar uma noção de interesses que teria se tornado uma "prisão elástica" para teorias da democracia incapazes de superar o liberalismo. Para o crítico, a entrada dos interesses e dos processos de barganha próprios à lógica do mercado na constituição democrática seria um dos fatores que impedem Habermas de ultrapassar uma noção liberal de política.

É preciso, porém, lembrar que, como vimos, tais interesses são "domesticados" no processo de constituição democrática por normas universalistas que impóe, no output do processo, a conformação racional do melhor argumento e a consequente universalização de interesses. A virtude, portanto, seria não fruto de uma identidade anterior intersubjetiva, mas resultado necessário de um procedimento que garante a legitimidade e, pois, a universalidade da decisão democrática. O retorno ao liberalismo, pela noção de interesses, efetiva-se na medida em que os pressupostos normativos do consenso são, via de regra, deslocados pelas intençóes estratégicas dos contendores.

Aqui, a crítica de Eisenberg nos leva na direção de outra questão formulada por Agnes Heller: as distorçôes no processo comunicativo, marca inocultável das relaçóes políticas na modernidade, são pouco ou mal explicadas pelo teórico. Nas palavras de Heller (1982, p. 25):

[...] the question of whether, and, if so, how, distortion of communication is motivated cannot be answered by Habermas; nor can he answer the question of what would motivate us to get rid of the distortion. The assumption that consensus can be achieved in a process of enlightenment is in fact no answer: the will to achieve consensus is the problem in question.

Para a filósofa, herdeira de Lukács, uma racionalidade existente emsi em um estado de reificação das relaçóes humanas pode apenas transformar-se em racionalidade parasi por uma escolha que, acrescentemos, deve ser virtuosa. Para fazer com que os pressupostos da ação comunicativa deixem de pairar por sobre as cabeças dos homens em sociedade e passem a efetivamente regrar suas açóes sociais, seria preciso escolher a racionalidade comunicativa como valor (HELLER, 1982, p. 29). Disso resulta a "insuficiência" de uma concepção de normas universalistas na medida em que, se estas não se impóem efetivamente, o recurso a tais normas permaneceria sempre carente de uma escolha valorativa. É preciso escolher o consenso por sobre a interação instrumental; 
e, nesse sentido, o déficit de virtude apontado por Eisenberg reaparece como déficit de racionalidade para si.

Precisamente porque o racional não se faz real por si mesmo, tal como a esperança habermasiana poderia induzir, e o real tampouco se faz racional, tal como a democracia em moldes volitivos e desejantes de Negri parece supor, faz-se preciso, a nosso juízo, uma concepção de democracia que ultrapasse tanto o automatismo protoliberal da sociabilidade em Negri quanto o universalismo formal de Habermas - e que possa vislumbrar algo além da reificação. Para isso, não obstante, há que se guardar dos dois autores a necessidade, incontornável, de remissão tanto à razão intersubjetiva quanto ao potencial criativo imanente da multidão.

\section{Considerações finais}

Se, como nos chama a atenção Marx, "a democracia é a verdade de todas as formas políticas", parece-nos, contudo, tarefa mais ardilosa identificar qual seria a específica verdade da democracia. Nossa análise dos fundamentos conceituais a partir dos quais Habermas e Negri erigem suas teorias da democracia indica, em primeiro lugar, que se o consenso é postulado comum das duas teorias, salta aos olhos a natureza disputada deste próprio consenso fundamental.

E, apesar de seu aparente desprezo pela noção de "consenso" -, "[...] não é por acaso que o conceito de consenso vem se identificando cada vez mais com o conceito de consumo" (NEGRI, 2003, p. 148) -, Negri, como vimos, herda de Espinosa um plano de imanência no qual é apenas a possibilidade de consenso que torna possível a democracia entre homens ontologicamente conflituosos.

Nesse sentido, deixa-se ver a abertura para uma noção volitiva de democracia em que a potência do corpo social define sem mediaçóes o conteúdo de sua própria sociabilidade. Segue desta concepção de democracia que o direito, enquanto forma exterior delimitadora das margens de liberdade da potência, passa a ser entendido, em chave negativa, como poder constituído, ou seja, como elemento necessariamente retrógrado em um processo de constituição que, respeitando o absoluto da democracia, precisa ser expansivo e sempre aberto ao aleatório da potência criativa. 
Para Habermas, no entanto, a fundamentação da democracia deliberativa a partir da noção de razão comunicativa lhe permite afirmar sem rodeios o consenso como base ontológica de uma democracia que, por seu turno, não se vê obliterada pelo direito. Para o filósofo alemáo, qualquer organização horizontal entre indivíduos dispostos à consolidação de um regime democrático que assegure a igualdade entre eles requer, a um só tempo, que se assegurem tanto a autonomia privada quanto a pública dos cidadáos. Se, por um lado, a própria democracia necessita do reconhecimento legal da autonomia privada dos cidadáos, por outro, essas liberdades individuais apenas podem ser autonomamente asseguradas por um regime de soberania popular. O direito passa assim, para Habermas, a condiçáo necessária de uma constituição democrática inclusiva.

A norma é, pois, requisito básico para que, em práticas comunicativas cada vez mais abrangentes via esfera pública, o corpo democrático possa autodeterminar os seus substratos éticos - ou, em outros termos, para que a multidão possa exercitar a sua anomalia potencial. A democracia, via norma, aparece entáo como imperativo categórico, na medida em que sua validade guarda nexo fundamental com um universalismo para além dos desejos de contexto. Se, para Espinosa, a ilusão teleológica está no fundar um governo a partir de uma equívoca confiança na razão da multidão, para Habermas, por sua vez, o erro teleológico está na inscrição plena da democracia no âmbito dos valores éticos vencedores. A democracia é categórica, aqui, porque não se funda apenas nas vontades da comunidade, mas também em uma norma universalista anterior.

$\mathrm{Na}$ recusa do direito, a teoria de Negri parece cair na aporia de, a um só tempo, atestar o absoluto da cupiditas da multidão no processo constituinte e identificar a exterioridade de uma soberania alçada, como poder constituído, para além da potência. Nesse sentido, se o plano de imanência habermasiano parece titubear diante do universalismo (quasi-transcendental) dos pressupostos da comunicaçáo - visto que estes permaneceriam sempre inscritos na prática social cotidiana; por seu turno, o imanentismo radical de Negri parece sucumbir diante de uma concepçáo parasitária de poder constituído, em que retorna a soberania, escamoteada, para o horizonte conceitual, situando-se para além da potência constituinte. Sobrevive, portanto, nas idas e vindas entre transcendência e imanência, entre forma e conteúdo, o enigma democrático 
- e perscrutar as ambivalências do plano de imanência parece ser condição inexpugnável de uma aprofundada reconstrução do horizonte normativo das teorias da democracia. $\mathrm{O}$ presente artigo pretendeu constituir um passo nessa direção.

\section{Referências}

BORRADORI, G. Filosofia em tempo de terror. Rio de Janeiro: Jorge Zahar, 2004.

CHAUÍ, M. Política em Espinosa. São Paulo: Cia. Das Letras, 2003.

EISENBERG, J. A democracia depois do liberalismo. Rio de Janeiro: Relume Dumará, 2003.

ESPINOSA. Tratado Político. São Paulo: Abril, 1973. (Coleção Os pensadores).

FOUCAULT, M. História da sexualidade (vol. 1): a vontade de saber. Rio de Janeiro: Graal, 1988.

Em defesa da sociedade. São Paulo: Martins Fontes, 1999.

Microfísica do poder. Rio de Janeiro: Graal, 2000.

. Ditos e escritos (vol. IV): Estratégia, poder-saber. Rio de Janeiro: Forense Universitária, 2003.

HABERMAS, J. Communication and the evolution of society. Boston: Beacon Press, 1979.

Para a reconstrução do materialismo histórico. São Paulo: Brasiliense, 1983.

Pensamento Pós-Metafísico. Rio de Janeiro: Tempo Brasileiro, 1990.

Between Facts and Norms. Cambridge: MIT, 1998.

The postnational constellation. Cambridge, MIT Press, 2001.

O discurso filosófico da modernidade. São Paulo: Martins fontes, 2002.

Diagnósticos do tempo: seis ensaios. Rio de Janeiro: Tempo Brasileiro, 2005.

HARDT, M.; NEGRI, A. Império. Rio de Janeiro: Record, 2001.

.; Multitude. New York: Penguin Press, 2004.

HEGEL, G. W. F. Princípios da filosofia do direito. São Paulo: Martins Fontes, 2003.

HELLER, A. Habermas and Marxism. In: HELD, D.; THOMPSON, J. B. Habermas, Critical Debates. Cambridge, MIT Press, 1982. p. 21-41. 
KANT, I. Filosofía de la historia. México D.F.: Fondo de Cultura Econômica, 1978.

KURZ, R. Les Habits Neufs de L’Empire. Clamecy: Lignes-Éditions Léo Scheer, 2003.

MARX, K. Crítica da Filosofia do direito de Hegel. São Paulo: Boitempo, 2005.

NEGRI, A. A anomalia selvagem. Rio de Janeiro: Ed. 34, 1993.

O Poder Constituinte. Rio de Janeiro: DP\&A, 2002.

Cinco Liçóes sobre Império. Rio de Janeiro: DP\&A, 2003.

SCHMITT, C. O conceito do político. Petrópolis: Vozes, 1992.

\section{Between formal procedure and savage content: immanence and democracy in Antonio Negri and Jürgen Habermas}

\section{Abstract}

Through a comparative analysis of Jürgen Habermas and Antonio Negri's democratic theories, the present article intends to clarify the conceptual foundations of both works. Its core consists in the discussion over the different inscriptions of each conception of democracy in a plane of immanence, with the premise that the cross-reading of these two authors favors a more acute comprehension of the theories' structural components, normative implications and limits. This study's main goal is to best define Negri's and Habermas' democratic theories as distinct alternatives (deliberation/substance), with some potential complementarities (e.g., the focus on consensus, be it as form or as content), that enable us to grasp the contemporary democratic dilemma.

Keywords: Theories of democracy. Immanence. Sovereignty. Jürgen Habermas. Antonio Negri.

Recebido em: 14.05.2017

Aprovado em: 28.10.2017 